\title{
Vanadium removal from spent sulfuric acid plant catalyst using citric acid and Acidithiobacillus thiooxidans
}

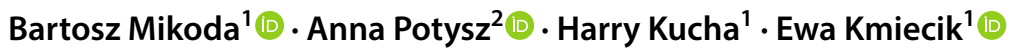

Received: 19 February 2020 / Revised: 26 August 2020 / Accepted: 5 October 2020

(c) The Author(s) 2020

\begin{abstract}
Spent catalysts being considered hazardous wastes exhibit a high metal content in mobile forms. In addition, growing demand for circular economy policy applications requires proper utilization of these wastes. This study aimed at the assessment of vanadium leaching from spent desulfurization catalyst derived from sulfuric acid plant dump located nearby a copper smelter. Chemical and phase composition of the catalyst has been characterized. The extraction has been performed using chemical (0.1-M and 1-M citric acid) and biological (biotic solution with Acidithiobacillus thiooxidans) methods, using different experimental parameters (pulp density, particle size, leaching time) to observe $\mathrm{V}$ leaching behavior and kinetics. The results revealed that both citric acid and bacteria carried out the extraction process well. The optimal parameters for acid leaching were $<0.2-\mathrm{mm}$ particle size and $2 \%$ pulp density, which allowed to leach out $95 \%$ of $\mathrm{V}$ from spent catalyst within $48 \mathrm{~h}$. The bacterially mediated extraction resulted in $93 \% \mathrm{~V}$ leached out within 21 days with $2 \%$ pulp density. The experiments showed that $\mathrm{V}$ present in the catalyst is susceptible to bioleaching and organic acid leaching with the latter being a quicker process.
\end{abstract}

Keywords Metal extraction $\cdot$ Waste management $\cdot$ Biohydrometallurgy $\cdot$ Process optimization

\section{Introduction}

To meet quality and/or environmental standards, sulfur dioxide has to be removed from products or gaseous emissions by a process called oxidative desulfurization [1], most commonly performed using catalysis-a process that relies on alteration of reaction rates using a solid-state catalyst [2]. The catalysts used are mainly highly porous, made of synthetic or natural $\mathrm{SiO}_{2}$ (cristobalite/tridymite), and contain different active substances, mainly metal (e.g., Co, Mo, V) salts or oxides (e.g., potassium pyro-sulfo-vanadates: $\mathrm{K}_{2} \mathrm{~S}_{2} \mathrm{O}_{7} \cdot \mathrm{V}_{2} \mathrm{O}_{5}$ ) in the pore spaces [3,4]. The life cycle of catalysts is limited (from seconds even up to 10 years);

Electronic supplementary material The online version of this article (https://doi.org/10.1007/s43452-020-00136-9) contains supplementary material, which is available to authorized users.

Bartosz Mikoda

bartosz.mikoda@agh.edu.pl

1 Faculty of Geology, Geophysics and Environmental Protection, AGH University of Science and Technology, al. A. Mickiewicza 30, 30-059 Kraków, Poland

2 Institute of Geological Sciences, University of Wrocław, Cybulskiego 30, 50-205 Wrocław, Poland during this time, the quality of catalysts gradually deteriorates, mainly by coke formation, by accumulation of metals, or active phase sintering ([5] and Ref. therein, [6]). The contaminated catalysts can be regenerated; however, after a few rejuvenation cycles, they become inactive and have to be replaced [5]. Smelting facilities, among others, use catalysts for $\mathrm{SO}_{2}$ oxidation to $\mathrm{SO}_{3}$, which is later utilized in sulfuric acid production. The generated amount of spent desulfurization catalyst (SDC) worldwide is about 40,000 tons per year [7]. In Poland, the accumulated mass of SDC amounts to 3000 tons in total [8]. Because of the metal accumulation, mainly in mobile forms, the spent catalysts are considered as hazardous waste [9]. The methods currently applied to utilize spent catalysts comprise landfilling, rejuvenation/regeneration, metal (bio)recovery, cement-based stabilization, and utilization in refineries ([10] and Ref. therein, [11]).

Vanadium, one of the commonly used metals in catalysis, has been also recognized as valuable metal in many medical and technological applications [12]. The occurrence of $\mathrm{V}$ in the environment stems from natural (magmatism, riverine, and oceanic suspended matter transport and deposition) and anthropogenic (e.g., from processing of heavy petroleum compounds or coal burning) emissions [13]. Global production of $\mathrm{V}$ has been doubled in the last 15 years, reaching 
73,000 tons per year in 2019 [14]. The vanadium content in ore is usually less than $2 \%$; thus, it is recovered as by-product or co-product in processing of other metals [7]. The main source of vanadium is the so-called urban mining (1-12\%), which is the processing of waste materials for recovery of this metal, that outscores traditional mining (1.8\%) in terms of $\mathrm{V}$ extracted [15]. The main consumption of vanadium $(85 \%)$ is connected with steel alloys manufacturing. The other applications comprise of: addition to Ti alloys, various chemicals, production of ferrovanadium $(\mathrm{FeV}$; alloying agent), or superconducting magnets [16]. A growing use of $\mathrm{V}$ takes place in vanadium redox-flow batteries (VFB), that are based on the fact that $\mathrm{V}$ occurs in four different oxidation states [17]. The $\mathrm{V}$ recycling rate worldwide is estimated at $<1 \%$ [18]. This fact, combined with growing demand for this element, and subsequently increasing global vanadium fluxes, may cause potential hazard for the environment. Therefore, a need to enhance the recovery rates of $\mathrm{V}$ from industrial waste is rapidly growing issue [19].

The recovery of vanadium from spent sulfuric acid catalysts has been widely studied in recent years with wide range of approaches combining biohydrometallurgy, hydrometallurgy, and pyrometallurgy. Mohanty et al. [20] tested the combination of $\mathrm{H}_{2} \mathrm{O} / \mathrm{Na}_{2} \mathrm{SO}_{3}$ leaching followed by precipitation and roasting, achieving $>99 \%$ of $\mathrm{V}$ extracted to the solution and the final product of $\mathrm{V}_{2} \mathrm{O}_{5}$ content at a level of $92.6 \%$. The hydropyrometallurgical approach (with roasting step before leaching) has also been tested by Wahoud et al., [21], where $98 \%$ of $\mathrm{V}$ was extracted using sulfuric acid baking and sulfuric acid leaching. However, these processes require elevated temperature and high-energy use. The work conducted by Mangini et al. [22] utilized electric potential to remove $\mathrm{V}$ from spent sulfuric acid catalyst, but the method was not optimal at the moment; nonetheless, it required no additional extractant (besides deionized water) and it is therefore worth further investigation. Therefore, (bio)hydrometallurgical approaches are believed to be more environment-friendly due to low-energy demand. The reagents used in hydrometallurgical studies were both inorganic and organic, acidic, and alkaline [23-27]. In particular, organic acids such as citric acid might be used in metal extraction due to their environmental safety, natural origin, and high degradability $[25,26]$. Another potential method that has been applied for recovery of metals from spent catalysts is bioleaching-applying bacteria or other microorganisms (e.g., fungi) for metal extraction from the material of interest [28]. The bioleaching has been recognized as environment-friendly, low-cost, and therefore competitive with other metal recovery/removal methods. Different microorganisms have been applied in biorecovery of metals from spent catalysts [29], but none of them has been applied to the sulfuric acid catalysts. The (bio)hydrometallurgical approaches allowed high metal extraction yields (even up to
$100 \%)$. Therefore, these methods are worth further efforts to optimize metal values extraction from spent catalysts. Such processing will allow to obtain pregnant leach solution for metal recovery and likely metal-free siliceous residue that can be then recycled again.

The inevitable part of a process optimization is a kinetic analysis of metal extraction. Every (bio)hydrometallurgical treatment of a solid sample may be considered as heterogenous solid-liquid interaction [30-32]. Therefore, the process going on within the system can be described as $\mathrm{A}_{\text {(liquid) }}+\mathrm{B}_{\text {(solid) }} \rightarrow$ products. According to Levenspiel [33], there are three possible factors that govern the leaching reaction: (1) diffusion through the fluid film, (2) diffusion through the solid product layer on the particle surface, and/ or (3) chemical reaction at the surface of the unreacted particle; the slowest of these three reactions is usually the one that controls the process. The two widely acclaimed models applied in kinetic analysis of leaching are shrinking-core model (SCM) and shrinking-particle model (SPM). In SCM, all three factors are considered as potentially governing the leaching process, whereas, in SPM, there are only two possibilities-fluid film diffusion and/or chemical reaction [30].

In the view of above-mentioned facts, the aim of this study was to evaluate vanadium extraction rates from spent desulfurization catalyst (SDC) generated in sulfuric acid plant in copper smelter. The organic lixiviant (citric acid) has been employed for hydrometallurgical reactions. The Acidithiobacillus thiooxidans lithotrophic sulfur-oxidizing strain has been employed for bioleaching experiments. The bench-scale investigation was aimed at defining optimal conditions for (bio)hydrometallurgical extraction of $\mathrm{V}$ from SDC. The obtained data were fitted into kinetic models to determine the experiment-controlling factors.

\section{Materials and methods}

\subsection{Material characterization}

\subsubsection{Sample preparation}

The SDC sample was received from sulfuric acid production unit in copper smelting facility. The catalyst is originally a yellow powder, but during the sulfur oxidation process, it forms yellow 10-mm granules (Fig. S1A, supplementary material). For the research purpose, the granules were comminuted and sieved through $100-\mu \mathrm{m}$ and $200-\mu \mathrm{m}$ sieves to obtain the smaller particles used in further studies (Fig. S1B, supplementary material). Such prepared sample has been directly used for extraction tests and for $\mathrm{pH}$ determination using EPA 9045D method [34]. The part of the sample has been crushed to $<100 \mu \mathrm{m}$ and $<5 \mu \mathrm{m}$ for determination of chemical and phase composition, respectively. One of the 
granules of as-received SDC sample was embedded in resin, cut horizontally in half, and polished with $1-\mu \mathrm{m}$ diamond paste (oil was used as lubricant). The polished section (Fig. S1C, supplementary material) has been subjected to microscopic observations.

\subsubsection{Microscopic observations}

The polished section of SDC was investigated in reflected light using Nikon Eclipse LV100POL microscope. Selected areas of the sample were observed using scanning electron microscope (SEM; FEI Quanta 200 FEG) coupled with EDAX energy-dispersion spectrometer (EDS). Following parameters were used: low vacuum mode, $20-\mathrm{kV}$ accelerating voltage, 10 -nA beam current, 50-s counting time, and $34^{\circ}$ take-off angle.

\subsubsection{Chemical composition}

The chemical composition of SDC sample was determined by X-ray fluorescence (XRF) using Rigaku ZSX Primus II apparatus (X-ray tube: end-window, with $\mathrm{Rh}$ anode; 4-kW power). The sample portion of $4.5 \mathrm{~g}$, powdered to $<100 \mu \mathrm{m}$, has been mixed with $1.5 \mathrm{~g}$ of CELLEOX $^{\circledR}$ binding aid to form a pellet. The wave intensities were calculated to oxide composition using the fundamental parameters method [35, 36].

\subsubsection{Phase composition}

The phase composition of the catalyst was determined by X-ray powder diffraction (XRD) using Rigaku MiniFlex 600 apparatus, on the sample portion of $0.5 \mathrm{~g}$, powdered to $<5 \mu \mathrm{m}$. The following settings were used for the analysis: $\mathrm{Cu}-\mathrm{K} \alpha$ radiation, $3^{\circ}-75^{\circ} 2 \theta$ range, and $0.05^{\circ}$ step width. The obtained data were processed using XRAYAN software coupled with JCPDS-ICDD 2013 database.

\subsection{Chemical leaching experiments}

The experiments using organic lixiviant-citric acid (CA) have been performed to assess the leaching potential of $\mathrm{V}$ from SDC sample and to establish the optimal process parameters. Citric acid has been selected as a proxy of a bacterially derived low-molecular-weight organic acid, which is easily biodegradable in the environment [27]. The CA used in the experiment was of analytical grade (Merck, Germany). The stock solution of $0.1 \mathrm{~mol} \mathrm{~L}^{-1}(0.1 \mathrm{M})$ and $1 \mathrm{~mol} \mathrm{~L}^{-1}$ (1 M) CA has been obtained by dissolving the appropriate amount of the reagent in ultrapure water (Millipore, Milli-Q). The tests have been performed in two sets, using batch mode. In the first set of experiments, the appropriate amounts of 0.1-M CA were mixed with SDC (fraction $<200 \mu \mathrm{m}$ ) in closed $50-\mathrm{cm}^{3}$ Falcon tubes and placed vertically on an orbital shaker. The constant parameters of the experiments were temperature of $22 \pm 1{ }^{\circ} \mathrm{C}$ and shaking speed of $100 \mathrm{rpm}$. The initial $\mathrm{pH}$ of CA was equal to 1.9 . Three pulp density has been used $(1 \%, 2 \%$, and $5 \%)$ to evaluate the impact of sample dose on extraction yields. Once above-mentioned parameters were evaluated, and the second set of experiments was performed using both $0.1-\mathrm{M}$ and 1-M CA and pulp densities of $10 \%$ and $20 \%$. Additionally, the particle sizes have been differentiated $(<100 \mu \mathrm{m}$ and 100-200 $\mu \mathrm{m}$ ) to evaluate the influence of this factor on $\mathrm{V}$ extraction from SDC. The appropriate amounts of catalyst samples have been placed in closed 250-mL PET bottles and mixed with CA solutions. The experimental parameters were the same as in the first set, except for the shaking speed, which was set at $300 \mathrm{rpm}$. The leachates were sampled after $8,24,48$, and $72 \mathrm{~h}$ for the kinetics investigation. The $\mathrm{pH}$ measurements in batch reactors were performed with Elmetron CP-411 pH meter (Elmetron, Poland) immediately after sampling campaigns. The sampled aliquots were filtered using $0.45-\mu \mathrm{m}$ Whatman ${ }^{\circledR}$ syringe filters, acidified with 0.1 $\mathrm{cm}^{3}$ of $1-\mathrm{M} \mathrm{HNO}_{3}$ and stored at $4{ }^{\circ} \mathrm{C}$ prior to analysis. All experiments were carried out at least in duplicates.

\subsection{Bioleaching experiments}

\subsubsection{Bacterial strain}

The bioleaching experiments were undertaken to study the effect of microbial activity on the extraction of $\mathrm{V}$ from SDC. The Gram-negative bacterial strain Acidithiobacillus thiooxidans (DSM 9463) was used in this study. The pure culture was provided by Leibniz-Institut DSMZ (Deutsche Sammlung von Mikroorganismen und Zellkulturen $\mathrm{GmbH}$ ). The bacteria were cultivated in salt growth medium consisting of 2-g $\left(\mathrm{NH}_{4}\right)_{2} \mathrm{SO}_{4}, 0.25-\mathrm{g} \mathrm{MgSO}_{4} \cdot 7 \mathrm{H}_{2} \mathrm{O}, 0.1-\mathrm{g}$ $\mathrm{K}_{2} \mathrm{HPO}_{4}, 0.1-\mathrm{g} \mathrm{KCl}$ and $1 \%$ (w/v) elemental sulfur per $1 \mathrm{dm}^{3}$ of ultrapure water (Millipore, Milli-Q), with $\mathrm{pH}$ adjusted to 2.5 using $10-\mathrm{M} \mathrm{H}_{2} \mathrm{SO}_{4}$ (all reagents of analytical grade, Merck, Germany). The culture was grown two times over a week to achieve the $\mathrm{pH}$ value of 1.7. Pregrown bacterial inoculum has been added to each biotic flask in $2 \%(\mathrm{v} / \mathrm{v})$ portion.

\subsubsection{Experimental design}

The experiments were designed to study the effect of pulp density $(1 \%, 2 \%, 5 \%, 10 \%$, and $20 \%$; first set consisted of $1 \%$ and $2 \% \mathrm{PD}$, second one of the remaining PDs) on $\mathrm{V}$ leaching yields. All laboratory wares were soaked overnight in $10 \% \mathrm{HNO}_{3}$. The tests were undertaken using batch mode in $50-\mathrm{cm}^{3}$ Erlenmeyer flasks. All materials (growth medium, flasks, catalyst, and elemental sulfur) were sterilized in 
$121{ }^{\circ} \mathrm{C}$ for $15 \mathrm{~min}$ prior to use (VWR autoclave). Each step of the experiment was taken under sterile conditions. Each flask was filled with appropriate amount of fresh growth medium (pH adjusted to 2.5) and SDC sample, as well as $2 \%$ $(\mathrm{w} / \mathrm{v})$ of elemental sulfur. Portions of $2 \%(\mathrm{v} / \mathrm{v})$ of bacterial inoculum were added to each biotic reactor. The same procedures (except of inoculum addition) were applied to abiotic control batches. The flasks were closed with cotton plugs and placed on an orbital shaker $(100 \mathrm{rpm})$ with controlled temperature $\left(28^{\circ} \mathrm{C}\right)$. The medium was sampled after 1,7 , 14,21 , and 28 days to investigate the kinetics of the process. The $\mathrm{pH}$ was controlled throughout the experiment; the measurements were done immediately after opening the reactors (Elmetron CP-411 pH meter). The sampled liquid portions have been filtered through Pureland ${ }^{\circledR} 0.22$ - $\mu \mathrm{m}$ syringe filters, diluted to $5 \mathrm{~cm}^{3}$ with ultrapure (Millipore Milli-Q) water and acidified with $0.1-\mathrm{cm}^{3} \mathrm{HNO}_{3}$ prior to the analysis. Both biotic and abiotic experiments were carried out at least in duplicates.

\subsubsection{Activity test}

After the bioleaching experiments were finished, the activity test for Acidithiobacillus thiooxidans culture was done [37]. A $1 \%(\mathrm{v} / \mathrm{v})$ of leach solution was added to fresh growth medium ( $\mathrm{pH} 2.5)$ and supplemented with $2 \%(\mathrm{w} / \mathrm{v})$ of elemental sulfur in $15-\mathrm{cm}^{3}$ Falcon tubes. The tubes were kept for 14 days in $28{ }^{\circ} \mathrm{C}$ to observe changes in solution opaqueness. When bacterial culture survived, the sulfur has been oxidized and settled on the bottom of the tube. When bacteria were absent, the sulfur remained floating on the medium's surface (Figure S2, supplementary material).

\subsection{Analytical procedures}

The concentration of vanadium has been determined using inductively coupled plasma mass spectrometry (ICP-MS, Perkin Elmer ELAN 6100) according to 17294-2 ISO standard [38]. The ${ }^{51} \mathrm{~V}$ isotope has been used for determination of $\mathrm{V}$ concentration. The calibration of the apparatus has been performed using ICP standards (Merck, Germany) of known vanadium concentrations. The quantification limit for
$\mathrm{V}$ was $0.001 \mathrm{mg} \mathrm{L}^{-1}$. Blank and duplicate control samples were analyzed to confirm the reliability of the results. The results of liquid phase analysis (in $\mathrm{mg} \mathrm{L}^{-1}$ ) were multiplied by liquid-to-solid ratios to express the mass of $\mathrm{V}$ in $\mathrm{mg}$ per kilogram of SDC.

\subsection{Kinetic analysis of (bio)hydrometallurgical vanadium extraction from SDC}

The equations that describe the mentioned kinetic models and specific reactions within them are presented in Table 1. For the purpose of the analysis, the right-hand sides of equations from Table 1 have been plotted as a function of time for each individual parameter examined. The $R^{2}$ coefficients were obtained from the graphs and put in Table 2. It must be noted that in most cases, the $R^{2}$ values were determined for incomplete datasets (e.g., for $1 \%$ and $2 \%$ PD for chemical leaching, or for bioleaching). This operation was made to improve the $R^{2}$ values, so that the model would fit better.

\section{Results and discussion}

\subsection{Material characteristics}

The usual composition of catalysts is based on porous support phase, covered by a layer of solid solution of metal salts [3]. The XRD-identified phases of SDC sample studied here are given in Fig. 1a, and the XRD patterns of (bio)leached residues are given in Fig. 1b (one figure due to similarity of the patterns). The main phase identified is $\mathrm{SiO}_{2}$ in the form of cristobalite and tridymite, which are typical support phases in this type of catalysts [3]. Apart from support phase, the vanadium oxide phase $\left(\mathrm{V}_{2} \mathrm{O}_{5}\right)$, and salt phases such as $\mathrm{NH}_{4} \mathrm{VOF}\left(\mathrm{SO}_{4}\right) \cdot 3 \mathrm{H}_{2} \mathrm{O}, \mathrm{K}_{2} \mathrm{~S}_{2} \mathrm{O}_{7}$ and $\mathrm{KAl}\left(\mathrm{SO}_{4}\right)_{2}$ were determined as crystalline phases in SDC sample. The phases identified in leached residues (Fig. 1b) were only $\mathrm{SiO}_{2}$ and $\mathrm{KAl}(\mathrm{SO} 4) 2$ with $\mathrm{V}$-containing phases removed from the residue. The components recognized using XRD have also been observed with SEM-EDS. Figure $2 a$, b shows that the porous $\mathrm{SiO}_{2}$ support phase and aggregates of needle-shaped $\mathrm{KAl}\left(\mathrm{SO}_{4}\right)_{2}$ crystals being SDC components. Additionally,
Table 1 Equations for heterogenous reaction kinetic models

\begin{tabular}{lll}
\hline Kinetic model & Reaction & Equation \\
\hline Shrinking-core model (SCM) & Product layer diffusion & $k_{\mathrm{d}} t=1-3\left(1-X_{\mathrm{V}}\right.$ \\
& & )$^{2 / 3}+2\left(1-X_{\mathrm{V}}\right)$ \\
& Chemical reaction & $k_{\mathrm{r}} t=1-\left(1-X_{\mathrm{V}}\right)^{1 / 3}$ \\
& Fluid film diffusion & $k_{\mathrm{f}} t=X_{\mathrm{V}}$ \\
Shrinking-particle model (SPM) & Chemical reaction & $k_{\mathrm{r}} t=1-\left(1-X_{\mathrm{V}}\right)^{1 / 3}$ \\
& Fluid film diffusion & $k_{\mathrm{f}} t=1-\left(1-X_{\mathrm{V}}\right)^{2 / 3}$ \\
\hline
\end{tabular}

Where $X_{\mathrm{V}}$-fraction of V extracted; $k_{\mathrm{d}}, k_{\mathrm{f}}, k_{\mathrm{r}}$-rate constants $\left(\mathrm{min}^{-1}\right) ; t$-time 
Table 2 Correlation coefficients $\left(R^{2}\right)$ of the kinetic models for various experimental parameters

\begin{tabular}{|c|c|c|c|c|c|}
\hline \multirow[t]{2}{*}{ Experimental parameters } & \multicolumn{3}{|c|}{ Shrinking-core model } & \multicolumn{2}{|c|}{ Shrinking-particle model } \\
\hline & $\begin{array}{l}\text { Fluid film dif- } \\
\text { fusion control }\end{array}$ & $\begin{array}{l}\text { Solid product } \\
\text { layer control }\end{array}$ & $\begin{array}{l}\text { Chemical } \\
\text { reaction } \\
\text { control }\end{array}$ & $\begin{array}{l}\text { Fluid film dif- } \\
\text { fusion control }\end{array}$ & $\begin{array}{l}\text { Chemical } \\
\text { reaction } \\
\text { control }\end{array}$ \\
\hline \multicolumn{6}{|l|}{ Citric acid leaching } \\
\hline \multicolumn{6}{|l|}{ Pulp density effect } \\
\hline $1 \%$ & 0.9004 & 0.9579 & 0.9509 & 0.9269 & 0.9509 \\
\hline $2 \%$ & 0.9758 & 0.9303 & 0.9373 & 0.9577 & 0.9373 \\
\hline $5 \%$ & 0.4895 & 0.4715 & 0.4805 & 0.4850 & 0.4805 \\
\hline $10 \%$ & 0.8220 & 0.8399 & 0.8390 & 0.8303 & 0.8390 \\
\hline $20 \%$ & 0.7108 & 0.6500 & 0.6824 & 0.6969 & 0.6824 \\
\hline \multicolumn{6}{|l|}{ Particle-size effect } \\
\hline$<100 \mu \mathrm{m}$ & 0.6048 & 0.6133 & 0.6094 & 0.6071 & 0.6094 \\
\hline $100-200 \mu \mathrm{m}$ & 0.8220 & 0.8399 & 0.8390 & 0.8303 & 0.8390 \\
\hline \multicolumn{6}{|l|}{ Acid conc. effect } \\
\hline $0.1 \mathrm{M}$ & 0.7108 & 0.6500 & 0.6824 & 0.6969 & 0.6824 \\
\hline $1 \mathrm{M}$ & 0.9990 & 0.9903 & 0.9977 & 0.9999 & 0.9977 \\
\hline \multicolumn{6}{|l|}{ Bioleaching } \\
\hline \multicolumn{6}{|l|}{ Pulp density effect } \\
\hline $1 \%$ & 0.9124 & 0.9825 & 0.9817 & 0.9528 & 0.9817 \\
\hline $2 \%$ & 0.9197 & 0.9255 & 0.9327 & 0.9261 & 0.9327 \\
\hline
\end{tabular}

Bold indicates biggest $\mathrm{R}$ values reflecting best fits to models

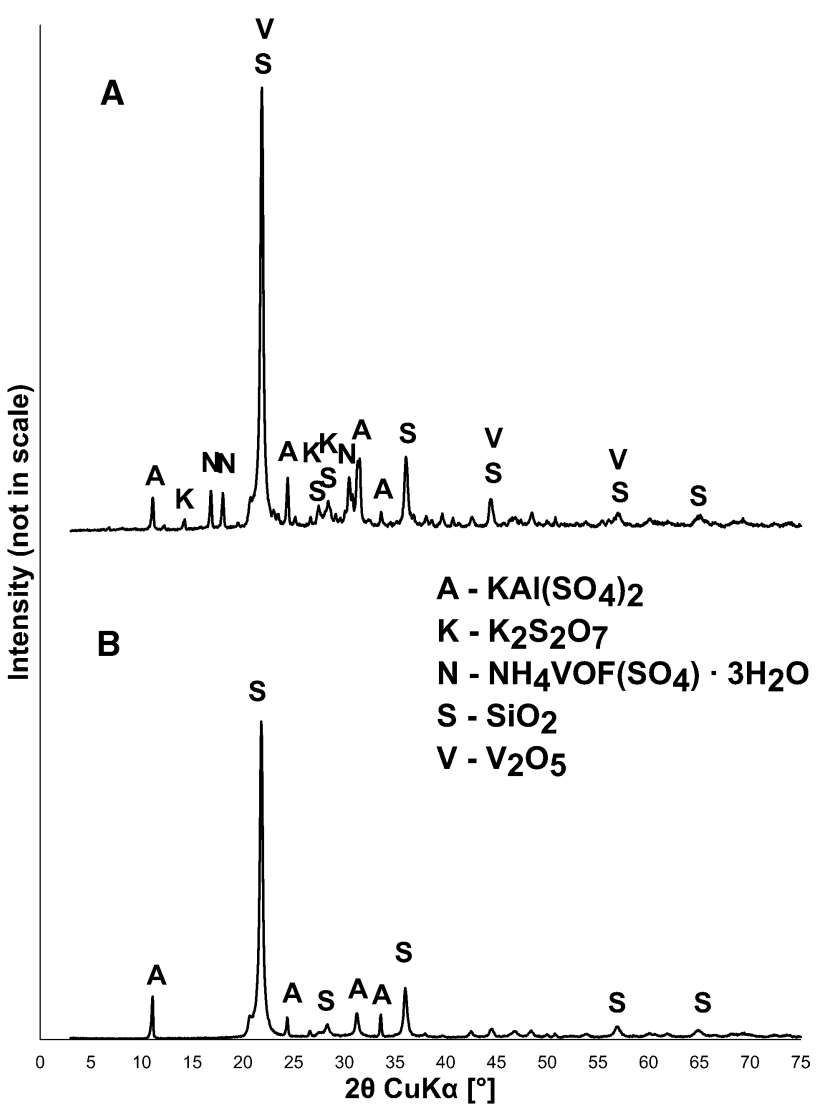

Fig. 1 XRD patterns of raw (a) and (bio)leached (b) spent desulfurization catalyst samples
EDS analysis confirmed the presence of potassium pyrosulfo-vanadate $\left(\mathrm{K}_{2} \mathrm{~S}_{2} \mathrm{O}_{7} \cdot \mathrm{V}_{2} \mathrm{O}_{5}\right)$ within the pore spaces. The uniformity of porous $\mathrm{SiO}_{2}$ matrix, observed in active catalysts, is disrupted in some areas, probably due to occurrence of waste precipitate [39].

The polished section of SDC has been treated with 0.1-M CA solution for $24 \mathrm{~h}$. The results of this treatment are shown in Fig. 2c, d. SEM photomicrographs illustrate that the porous $\mathrm{SiO}_{2}$ matrix has been digested by the CA solution, and $\mathrm{KAl}\left(\mathrm{SO}_{4}\right)_{2}$ crystallites have not been etched. In addition, the residue from CA experiments has been subjected to XRD measurements. The X-ray data confirmed that the remaining phases after $\mathrm{CA}$ treatment were $\mathrm{SiO}_{2}$ polymorphs (cristobalite and tridymite) and $\mathrm{KAl}(\mathrm{SO} 4)_{2}$ (Fig. 1b).

Figure 2e, f illustrates precipitated $\mathrm{SiO}_{2}$ rich in $\mathrm{V}$ (up to $4.5 \% \mathrm{~V}$ according to EDS measurements) that occurred during acid leaching (Fig. 2e), as well as bioleaching (Fig. 2f).

The main chemical component of spent catalyst (shown in Table 3) is $\mathrm{SiO}_{2}$ (65.5\%), which is connected with the presence of cristobalite/tridymite as dominant phases. The other abundant components are $\mathrm{SO}_{3}$ and $\mathrm{K}_{2} \mathrm{O}(15.5 \%$ and $8.8 \%$, respectively) that are related to solid solution of salts commonly used in such type of catalysts. The $\mathrm{V}_{2} \mathrm{O}_{5}$ content has been determined at the level of $5.5 \%\left(55,048 \mathrm{mg} \mathrm{kg}^{-1}\right)$, which is equal to $30,836 \mathrm{mg} \mathrm{kg}^{-1}$ of $\mathrm{V}$. Some amounts of $\mathrm{Al}_{2} \mathrm{O}_{3}, \mathrm{Na}_{2} \mathrm{O}$, and $\mathrm{Fe}_{2} \mathrm{O}_{3}(1.67 \%, 1.64 \%$, and $0.73 \%$, respectively) are also present in the SDC sample. The chemical composition after acid leaching (Table 3 ) determined by 


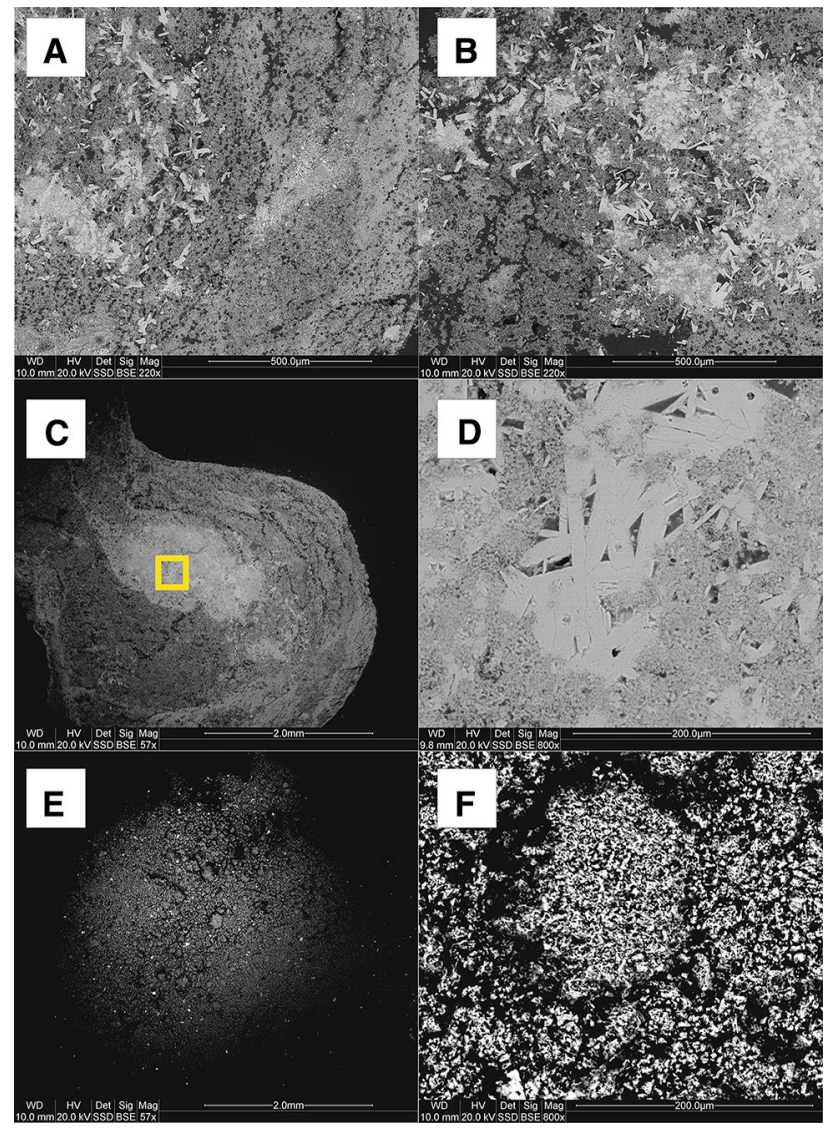

Fig. 2 a, b BSE photomicrographs of spent desulfurization catalyst, showing needle-shaped, euhedral $\mathrm{KAl}\left(\mathrm{SO}_{4}\right)_{2}$ crystals (light gray) embedded in porous $\mathrm{V}$-doped $\mathrm{SiO}_{2}$ matrix (gray-to-dark gray); c, d BSE photomicrographs illustrating polished section of spent desulfurization catalyst after application of $0.1-\mathrm{M}$ citric acid droplet on the surface; $\mathbf{c}$ is a general overview of catalyst polished section after citric acid treatment, whereas $\mathbf{d}$ is a magnification of the yellow-boxed area from $\mathbf{c}$, showing porous $\mathrm{SiO}_{2}$ matrix (darker gray) disturbed by citric acid, while $\mathrm{KAl}\left(\mathrm{SO}_{4}\right)_{2}$ (lighter gray) crystals remained virtually unchanged; e, f BSE photomicrographs of spent desulfurization catalyst; $\mathbf{e}$ is a general overview of catalyst after citric acid leaching; $\mathbf{f}$ is an overview of the precipitate occurring during bioleaching, composed of random mixture of $\mathrm{SiO}_{2}$ and $\mathrm{V}_{2} \mathrm{O}_{5}$

Table 3 Chemical composition (determined by WDXRF) and specific surface area of raw, acid leached, and bioleached spent desulfurization catalyst samples

Chemical com- Raw SDC Acid leached SDC Bioleached SDC pounds (wt.\%)

\begin{tabular}{llll}
\hline $\mathrm{Na}_{2} \mathrm{O}$ & 1.64 & 0.08 & 0.05 \\
$\mathrm{Al}_{2} \mathrm{O}_{3}$ & 1.67 & 1.53 & 0.51 \\
$\mathrm{SiO}_{2}$ & 65.5 & 92.0 & 96.5 \\
$\mathrm{SO}_{3}$ & 15.5 & 4.10 & 2.20 \\
$\mathrm{~K}_{2} \mathrm{O}$ & 8.77 & 1.33 & 0.35 \\
$\mathrm{~V}_{2} \mathrm{O}_{5}$ & 5.50 & 0.19 & 0.22 \\
$\mathrm{Fe}_{2} \mathrm{O}_{3}{ }^{\mathrm{a}}$ & 0.73 & 0.52 & 0.13 \\
$\mathrm{MgO}$ & 0.23 & 0.06 & 0.02 \\
Total & 99.6 & 99.8 & 100 \\
\hline
\end{tabular}

${ }^{\mathrm{a}}$ Total Fe
XRF was dominated by $\mathrm{SiO}_{2}(92 \%)$, with $\mathrm{V}_{2} \mathrm{O}_{5}$ at a level of $0.19 \%$. The bioleached spent desulfurization catalyst (Table 3) consisted of $96.5 \% \mathrm{SiO}_{2}$ with the $0.22 \% \mathrm{~V}_{2} \mathrm{O}_{5}$ content The chemical composition reflects the mineralogical research, which showed that $\mathrm{KAl}(\mathrm{SO} 4)_{2}$ was undeteriorated $\left(\mathrm{Al}_{2} \mathrm{O}_{3}\right.$ content in acid leached and bioleached samples at a level of $1.53 \%$ and $0.51 \%$, respectively) while siliceous matrix that contains $\mathrm{V}$ has been affected with $\mathrm{CA}$ treatment.

The $\mathrm{pH}$ value measured for the SDC sample was equal to 1.88 , which shows that the waste catalyst is highly acidic, probably due to presence of sulfur in its structure.

\subsection{Bioleaching efficiency and kinetics}

The results of vanadium extraction using $0.1 \mathrm{MCA}$ (first set of experiments-see "Chemical leaching experiments" section) are presented in Fig. 3a, and the $\mathrm{pH}$ profile recorded in the duration of the experiment is shown in Fig. 3b. The general observation drawn from analyzing the recovery results is that the diversification of pulp density (PD) has a very minor effect on vanadium leaching from SDC. For all the different PDs applied, the extraction of V reached $>59 \%$ (up to $68 \%$ ) in the first $8 \mathrm{~h}$. The extension of $\mathrm{V}$ extraction time up to $48 \mathrm{~h}$ of the process enabled to extract $90 \%$ of V (PD $1 \%$ ) and $95 \%$ of $\mathrm{V}(\mathrm{PD} 2 \%$ ) indicating the preference for the
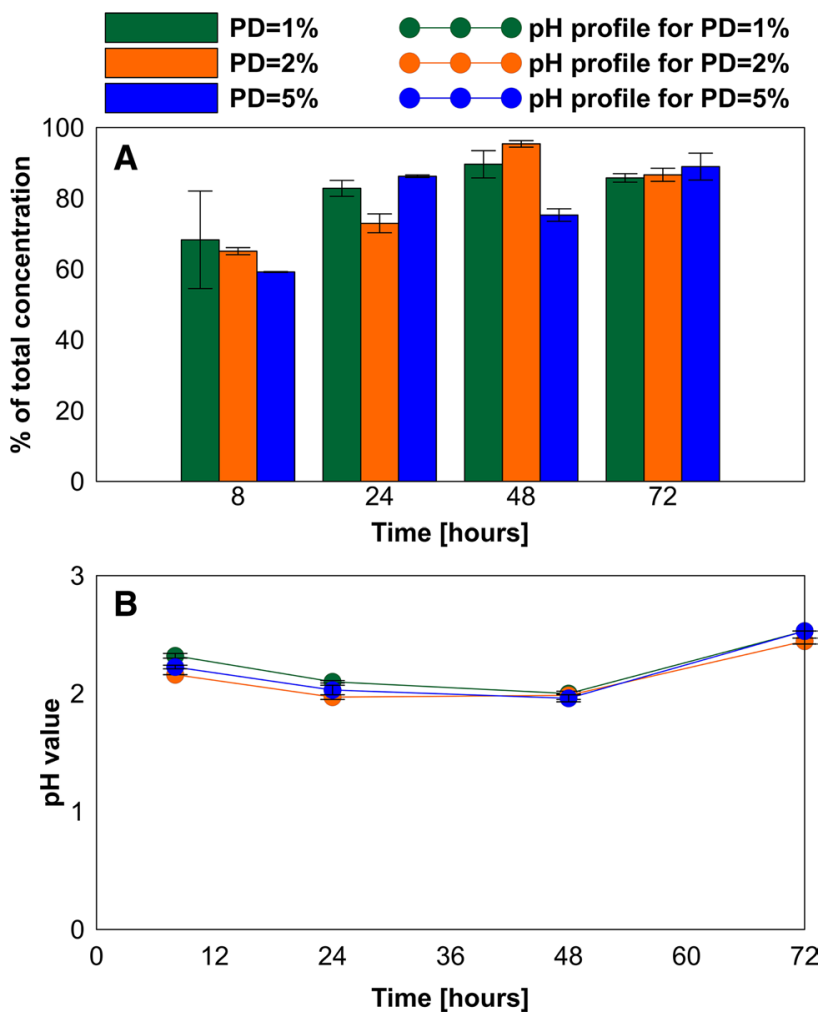

Fig. 3 Vanadium leaching yields by $0.1-\mathrm{M}$ citric acid (a) and $\mathrm{pH}$ profiles recorded throughout the experiment (b). $P D$ pulp density 
use of higher PD. It has to be noted that economically viable extraction process requires the use of possibly high PD, because, at the same time, it reduces the amount of chemical per $\mathrm{kg}$ of sample [40]. In case of 5\% PD, the $\mathrm{V}$ extraction yields after 24 and $48 \mathrm{~h}$ were $86 \%$ and $75 \%$, respectively. At the end of the extraction test $(72 \mathrm{~h})$, the amounts of $\mathrm{V}$ released were $86 \%, 87 \%$, and $89 \%$ for $1 \% \mathrm{PD}, 2 \% \mathrm{PD}$, and $5 \% \mathrm{PD}$, respectively. The $\mathrm{pH}$ profiles recorded throughout the experiment (Fig. 3b) show that the $\mathrm{pH}$ values at each of the sampling campaign was virtually independent of pulp density applied. After $8 \mathrm{~h}$, the measured $\mathrm{pH}$ values were 2.16-2.32. These values are higher than the $\mathrm{pH}$ value of the SDC sample (1.88) and the initial $\mathrm{pH}$ value of CA (1.9). The potential explanation for this may be the high $\mathrm{SiO}_{2}$ content in the SDC sample, which may account for buffering effect in the solution $[41,42]$. In the next phases of the experiment, the $\mathrm{pH}$ decreased to $1.97-2.10$ and 1.96-2.00 after $24 \mathrm{~h}$ and $48 \mathrm{~h}$, respectively. The increase of $\mathrm{pH}$ values up to $2.45-2.53$ was noted at the end of the experiment. The $\mathrm{pH}$ values are in good agreement with the extraction yields, as shown in Fig. 3a. Increase of extraction rates has happened simultaneously with the decrease of $\mathrm{pH}$ values. No specific relation between the rate of $\mathrm{pH}$ decrease and the rate of increase of $\mathrm{V}$ concentration in the leach solution has been observed. The only exception is the experiment with 5\% PD, where the decrease of $\mathrm{pH}$ has been observed along with the decrease of extraction yield. The reason of this downfall was likely a rapid precipitation of $\mathrm{V}$ (e.g., with silica gel), which was later dissolved again and the $\mathrm{V}$ concentration in the solution has increased. This assumption has been confirmed by SEM observations (Fig. 2e).

The second set of experiments (see Sect. 2.2) revealed that not only the pulp density, but also molar concentration of CA and the particle size play a role in the leaching process (Fig. 4).

For the $<100 \mu \mathrm{m}$ particle size, the obtained yields increased slightly with increasing CA molar concentration from 0.1 to $1 \mathrm{M}$. When $0.1-\mathrm{M}$ CA and $10 \% \mathrm{PD}$ were applied (Fig. 4a), 69\% of V has been released within first $8 \mathrm{~h}$ and extension of leaching time to $72 \mathrm{~h}$ improved extraction reaching $71 \%$ (Fig. 4a). For $20 \%$ PD (Fig. 4a) with $0.1 \mathrm{M}$ $\mathrm{CA}$, the initial yield ( $8 \mathrm{~h}$ ) was $34 \%$ and increased up to $73 \%$ after $48 \mathrm{~h}$. As experiment progressed from 48 to $72 \mathrm{~h}$, no improvement in $\mathrm{V}$ extraction was observed (68\%). In case of $1 \mathrm{M} \mathrm{CA}$ and $10 \% \mathrm{PD}$ (Fig. $4 \mathrm{~b}$ ), the initial yield ( $8 \mathrm{~h}$ ) was very promising - the solution contained $71 \%$ of total $\mathrm{V}$ and decreased slightly at the further stages of the experiment (e.g., $58 \%$ after $48 \mathrm{~h}$ ). The opposite situation was observed for $20 \%$ PD (Fig. 4b). $8 \mathrm{~h}$ of experiment brought $51 \%$ extraction yield that increased to $65 \%$ after $24 \mathrm{~h}$ and $87 \% \mathrm{~V}$ extraction yield was achieved after $72 \mathrm{~h}$.
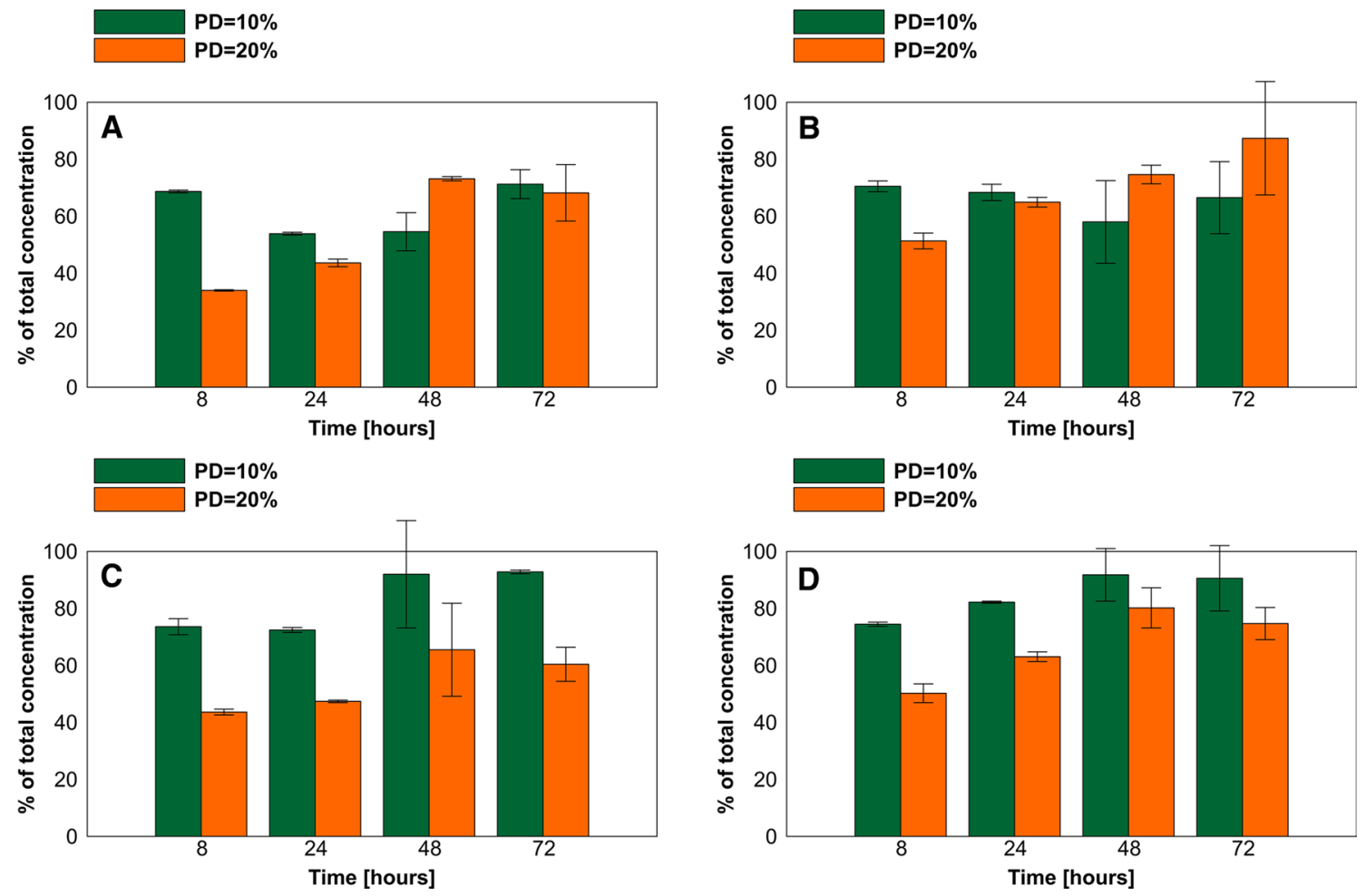

Fig. 4 Vanadium yields obtained by leaching at: 0.1-M citric acid and $<100-\mu \mathrm{m}$ particle size (a); 1-M citric acid and $<100-\mu \mathrm{m}$ particle size (b); $0.1-\mathrm{M}$ citric acid and 100-200 $\mu \mathrm{m}$ particle size (c); 1-M citric acid and 100-200 $\mu \mathrm{m}$ particle size (d). $P D$ pulp density 
Application of larger particles $(100-200 \mu \mathrm{m})$ resulted in higher final extraction yields, which was rather surprising as the reduction of particle size is believed to enlarge the available reaction surface and therefore increase the leaching yields $[43,44]$. In case of both $0.1-\mathrm{M}$ and 1-M CA, the smaller PD (10\%) gave better results in terms of $\mathrm{V}$ amount extracted. For 0.1-M CA and 10\% PD applied, 70\% of V was extracted after $8 \mathrm{~h}$ and $24 \mathrm{~h}$ (Fig. 4c). The final phase of the experiment (48-72 h) showed the V leaching yield at the level of $\sim 93 \%$. In contrast, $20 \%$ PD enabled to reach V yields at the level of $44-65.5 \%$ with the latter being reached after $24 \mathrm{~h}$ (Fig. 4c). Increase of molar concentration of CA to $1 \mathrm{M}$ resulted in slightly higher $\mathrm{V}$ extraction yields (Fig. 4d). In case of $10 \% \mathrm{PD}$, the yield after $8 \mathrm{~h}$ was $74.5 \%$ and the gradual increase to $82 \%(24 \mathrm{~h})$ and $91-92 \%(48-72 \mathrm{~h})$ was observed. Conversely, application of $20 \%$ PD and 1 M CA led to $50 \%$ of $\mathrm{V}$ leaching after $8 \mathrm{~h}$. The $\mathrm{V}$ leaching yield similarly increased after 24 and $48 \mathrm{~h}$ to the level of $63 \%$ and $80 \%$, respectively. The final extracted amount of $\mathrm{V}$ was $75 \%$ after $72 \mathrm{~h}$ (Fig. 4d). The $\mathrm{pH}$ profiles recorded during the experiments varied with different experimental parameters. The most significant difference can be observed for the different molar concentrations of CA (Fig. 5). The initial $\mathrm{pH}$ of $0.1 \mathrm{M} \mathrm{CA}$ was equal to 1.98. After $8 \mathrm{~h}$, the $\mathrm{pH}$ for all applied parameters decreased to 1.59-1.76. At this stage, higher $\mathrm{pH}$ values were observed for $10 \%$ PD than for $20 \% \mathrm{PD}$. After $24 \mathrm{~h}$, the $\mathrm{pH}$ values were in the range of 1.84-1.96. The increase of $\mathrm{pH}$ values was slow and the final $\mathrm{pH}$ range was 1.79-2.07. The exception was noted for 100-200 $\mu \mathrm{m}$ and 10\% PD, where the $\mathrm{pH}$ values decreased with time (Fig. 5). The ranges of $\mathrm{pH}$ values for the experiment using $1 \mathrm{M} \mathrm{CA}$ were narrower than for $0.1 \mathrm{M} \mathrm{CA}$. The initial $\mathrm{pH}$ of $1 \mathrm{M} \mathrm{CA}$ was equal to 1.36 . After $8 \mathrm{~h}$, the $\mathrm{pH}$ values decreased to the range of 1.13-1.21. After 24 and $48 \mathrm{~h}$, the $\mathrm{pH}$ values were $1.16-1.20$ and $1.12-1.15$, respectively. Final values of $\mathrm{pH}$ after $72 \mathrm{~h}$ were equal to $1.08-1.10$
(Fig. 5). No specific relationship has been observed between $\mathrm{pH}$ values and extraction yields for this set of experiments. The Eh values were also recorded throughout both sets of experiments. The results are presented on $\mathrm{Eh} / \mathrm{pH}$ diagram (Fig. 6). The graph shows that the Eh values were mostly between 400 and $700 \mathrm{mV}$. These values combined with $\mathrm{pH}$ values between 1 and 2 were compared with Pourbaix diagram for vanadium [45]; the results suggest that vanadium is present in the CA solution in the form of $\mathrm{VO}^{2+}$ ion, which means that $\mathrm{V}$ exhibits +4 oxidation state. This is congruent with the blue color of the solution, typical for $\mathrm{V}^{4+}$ ions. The vanadium ions presumably did not form any complexes with citric acid, but are just dispersed in the solution, in which they are stable due to low $\mathrm{pH}[45,46]$ and bonded with one another by oxygen bridging [47]. Therefore, it may be easy to precipitate vanadium ions using, e.g., ammonium salts or simply by increasing the $\mathrm{pH}$ of the solution, as proved by other authors $[24,25]$.

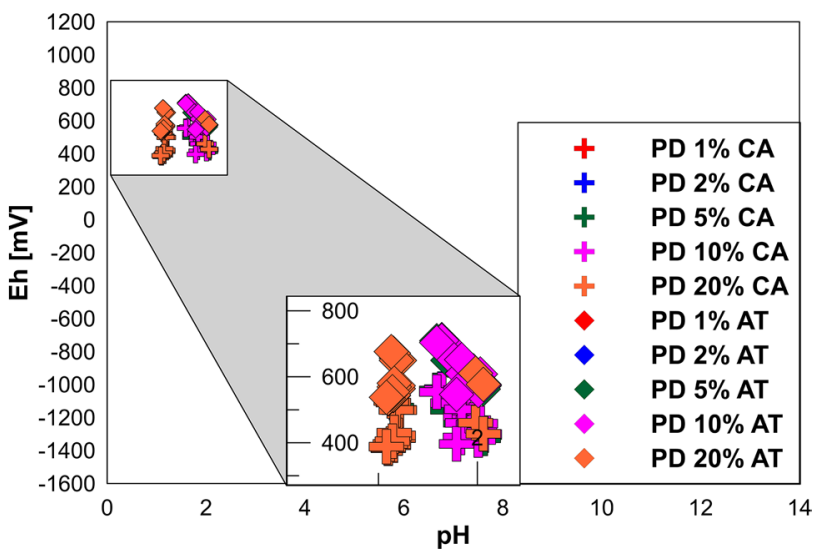

Fig. 6 The pH/Eh diagram for leaching of spent catalyst using citric acid (CA) and Acidithiobacillus thiooxidans (AT). $P D$ pulp density

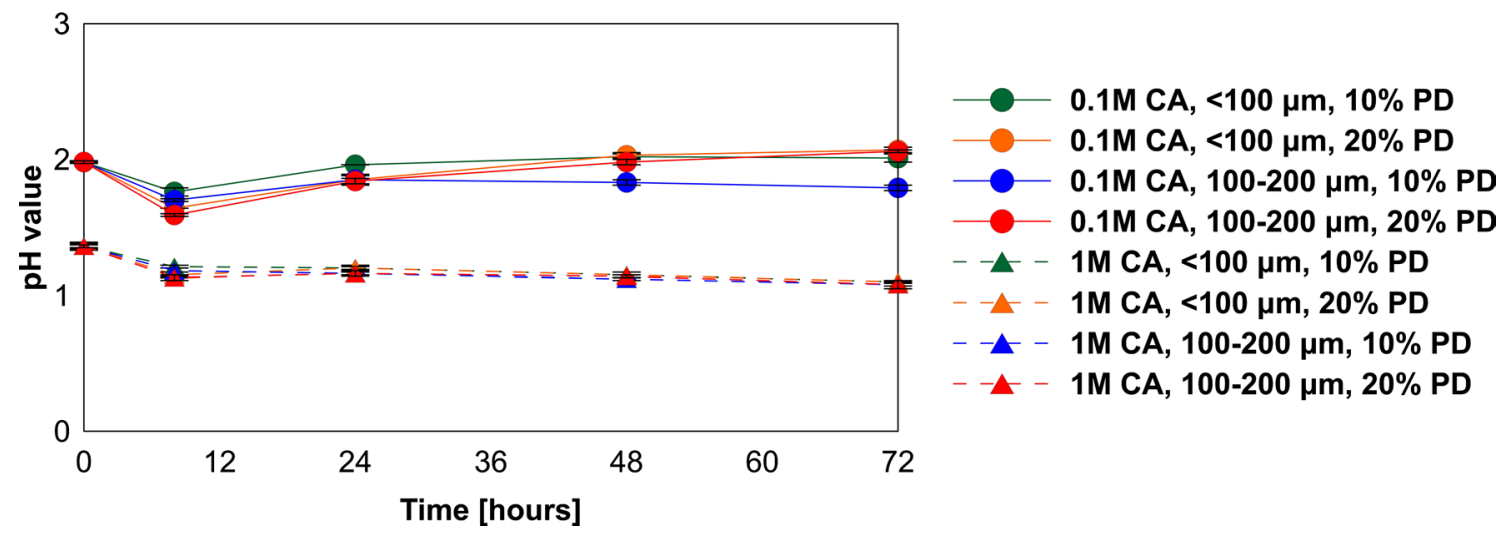

Fig. $5 \mathrm{pH}$ profiles recorded during citric acid leaching of spent desulfurization catalyst in various experimental conditions. $C A$ citric acid, $P D$ pulp density 
The $\mathrm{V}_{2} \mathrm{O}_{5}$ concentration after CA leaching (Table 3) was determined at $1940 \mathrm{mg} \mathrm{kg}^{-1}$, which is equal to $1087 \mathrm{mg} \mathrm{kg}^{-1}$ of $\mathrm{V}$. When one compares this value to the initial $\mathrm{V}$ concentration $\left(30,836 \mathrm{mg} \mathrm{kg}^{-1}\right)$, the leaching yield is at the level of $96.5 \%$, which is even higher than determined by ICP-MS (93\%). This highlights the need for material characterization to make appropriate mass balance in the leaching system.

The efficiency of $\mathrm{V}$ bioleaching, expressed as percentage of total V concentration in SDC sample, has been illustrated on Fig. 7a for biotic experiments and on Fig. $7 b$ for corresponding abiotic controls. The evolution of $\mathrm{pH}$ profiles recorded during both biotic and abiotic experiments has been displayed in Fig. 7c. The use of S-oxidizing bacteria enhanced the extraction relative to abiotic conditions and allowed to obtain the maximum $\mathrm{V}$ yield of $93 \%$ (PD 1\%, 21 days). On the other hand, abiotic control experiments
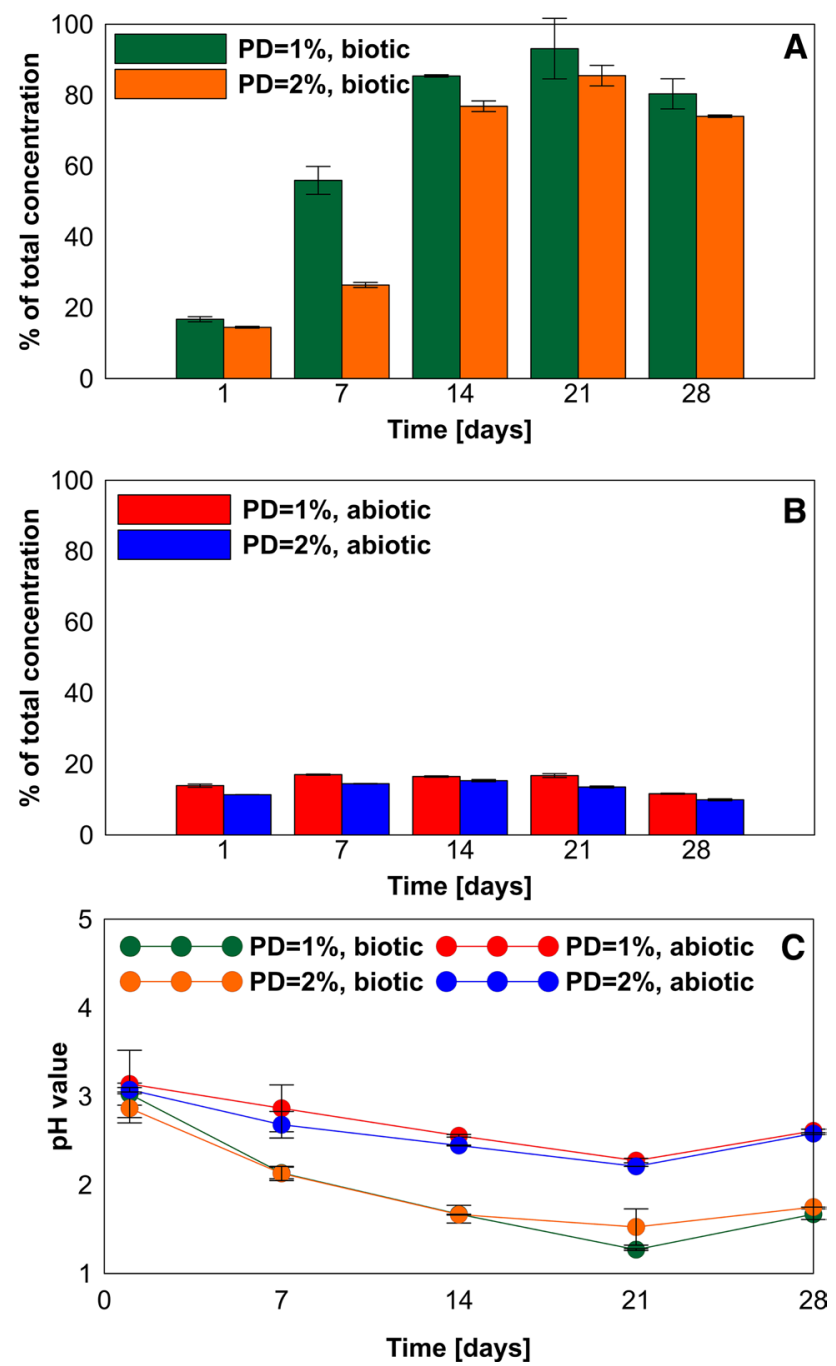

Fig. 7 Vanadium leaching yields obtained by: Acidithiobacillus thiooxidans (a), abiotic control leaching (b), and $\mathrm{pH}$ profiles recorded throughout the experiment (c) for $1 \%$ and $2 \%$ PD. PD pulp density revealed that leaching of SDC yielded no more than $17 \%$ of $\mathrm{V}$. In general, the pulp density (PD) applied had a minor influence on $\mathrm{V}$ extraction yields during biotic procedure. The exception has been noted after 7 days, where the $\mathrm{V}$ extraction yield with $1 \%$ PD applied (55\%) was double the yield for 2\% PD (26.5\%). During the first day of experiment, as much as $17 \%$ and $15 \%$ of $\mathrm{V}$ has been extracted for $1 \%$ PD and 2\% PD, respectively (Fig. 7a). The abiotic leaching yielded $14 \%$ and $11.5 \%$ for $1 \%$ PD and $2 \%$ PD, respectively, during the first $24 \mathrm{~h}$. The maximum recovery has been noted for 21-day extraction time, when as much as $93 \%$ and $85.5 \%$ of total V in SDC sample has been released for 1\% PD and $2 \% \mathrm{PD}$, respectively. At the end (28 days) of the bioleaching experiment, the decrease of $\mathrm{V}$ concentration in the solution has been noted. The final extraction yields were $80 \%$ for $1 \%$ PD and $74 \%$ for $1 \%$ PD. The extracted amounts of V in abiotic control reactors were constant in time, but the decrease from 14 to $11 \%$ (for $1 \% \mathrm{PD}$ ) and from 11 to $9 \%$ (for $2 \%$ PD) in the final phase has also been observed (Fig. 7b). The bacterial activity has been confirmed by the change of the solution color, that evolved with time (Fig. S3 A-C, supplementary material). The intensity of green hue in the solution (that subsequently turns blue) can be associated with the reduction of $\mathrm{V}$ oxidation state from +5 (yellow, the initial color of the SDC sample, as well as the color of $\mathrm{V}^{5+}$ ions in the solution) to +4 . This phenomenon has been proven by Bredberg et al. [48], who confirmed that the sulfur-oxidizing (Acidithiobacillus thiooxidans) and iron-oxidizing (Acidithiobacillus ferrooxidans) bacteria can reduce $\mathrm{V}$ from $\mathrm{V}^{5+}$ to $\mathrm{V}^{4+}$. It was also confirmed by $\mathrm{pH} / \mathrm{Eh}$ diagram (Fig. 6) where the Eh values measured fell into $\mathrm{VO}^{2+}$ region from Pourbaix diagram [45]. The $\mathrm{pH}$ profiles recorded during the procedure (Fig. 7c) show that the $\mathrm{pH}$ values in both biotic and abiotic experiments have decreased until 21 days of reaction. The initial $\mathrm{pH}$ value of the growth medium was 2.5 . After the first day, the $\mathrm{pH}$ increased to 2.87-3.03 for biotic and 3.08-3.14 for abiotic experiments. The $\mathrm{pH}$ values observed after 21 days were $1.27-1.53$ for biotic and 2.21-2.28 for abiotic reactors. The final $\mathrm{pH}$ values measured after 28 days were 1.67-1.75 for biotic experiments and 2.58-2.61 for abiotic control. The $\mathrm{pH}$ profiles for biotic experiments are reflecting the $\mathrm{V}$ recovery yields. The decrease of $\mathrm{pH}$ is connected with the increase of metal recovery yield during 21 days, which suggests that the sulfuric acid produced by Acidithiobacillus thiooxidans led to the improvement of $\mathrm{V}$ dissolution. An increase of $\mathrm{pH}$ and subsequent lowering of $\mathrm{V}$ concentration in the solution might suggest that the bacterial activity has been inhibited in the final part of the experiment. The bacterial activity test conducted after the biotic experiment (Fig. S2A, S2B, supplementary material) showed that some sulfur is still floating on the surface of the medium (Fig. S2B), which indicates only partial survival of bacteria during the experiment. The suppression of bacterial aid may 
have led to the partial precipitation of vanadium. The activity test for abiotic experiments (Fig. S2C, S2D, supplementary material) showed that no bacterial activity took part in the $\mathrm{V}$ leaching by growth medium. The decrease of $\mathrm{pH}$ value during abiotic control experiments may be associated with low $\mathrm{pH}$ of the sample (1.88) that enhanced the $\mathrm{pH}$ decrease during the abiotic experiment.

In the second set of bioleaching experiments, the pulp densities have been increased to 5\%,10\%, and 20\% (Fig. 8a, b), since an increase of this parameter has been reported as helpful in achieving higher extraction yields [49]. Figure 8c shows the $\mathrm{pH}$ profiles recorded during bioleaching. In general, first $24 \mathrm{~h}$ of the experiment gave very promising results, as the yields were higher compared to these from the first set of experiments. The extracted amounts were: $33 \%$ (5\% PD), $35 \%$ (10\% PD), and 25\% (20\% PD) (Fig. 8a), which were
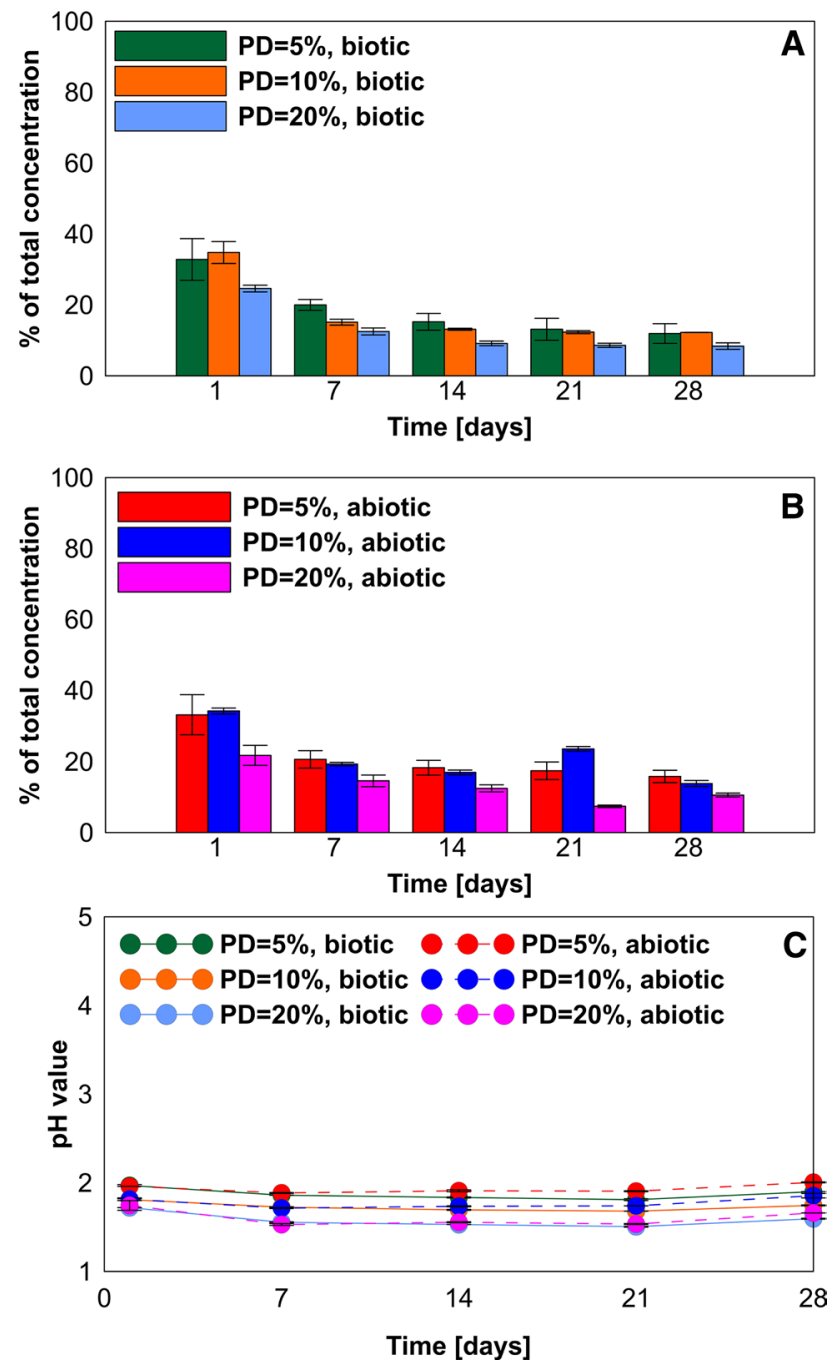

Fig. 8 Vanadium leaching yields obtained by: Acidithiobacillus thiooxidans (a), abiotic control leaching (b), and $\mathrm{pH}$ profiles recorded throughout the experiment (c) for 5\%,10\%, and 20\% PD. PD pulp density twice those for $1 \%$ and $2 \%$ PD. However, a sharp decrease was noted after 7 days, and the measured values were $20 \%$, $15 \%$, and $12.5 \%$ for $5 \%, 10 \%$, and $20 \%$ PD, respectively. The decrease continued with time and final yields were established at $12 \%$ for $5 \%$ and $10 \%$ PD and $8.5 \%$ for $20 \%$ PD (Fig. 8a). Virtually, the same trend has been noted for abiotic control experiments (Fig. 8b), which might be the proof that no bacterial activity took place during the experiments. The bacterial culture survived according to activity test conducted after the extraction procedure. The reason for hampering bacterial activity could be connected with an improper mixing of the sample with the lixiviant, as well as inappropriate diffusion of oxygen, or even shortage of oxygen in higher PD conditions [50].

The extracted amount of $\mathrm{V}$ has been compared with the content of sulfate in the solution. The sulfate content as a function of time has been presented in Fig. 9. In case of the first set of experiments (1\% and 2\% PD), the sulfate content was increasing with time for the biotic experiment (Fig. 9a). The increase during first 7 days was slow, but faster for $1 \% \mathrm{PD}$, which is congruent with the increase of $\mathrm{V}$ concentration, which also was faster for 1\% PD (Fig. 7a). After 7 days, the increase of sulfate content was more rapid and the concentration kept growing until the termination of the experiment; the content after 28 days was fourfold higher for $1 \%$ PD (900-3600 $\mathrm{mg} \mathrm{L}^{-1}$ ) and threefold higher for $2 \% \mathrm{PD}\left(1200-3900 \mathrm{mg} \mathrm{L}^{-1}\right)$ than after first day of the experiment. Contrarily, the sulfate content for the second set of biotic experiments was higher than for the first set (due to bigger portion of S-rich waste), while the function of time was either fairly constant or slightly growing (2300-1900 $\mathrm{mg} \mathrm{L}^{-1}$ for $5 \% \mathrm{PD}, 4000-4400 \mathrm{mg} \mathrm{L}^{-1}$ for $10 \% \mathrm{PD}$, and $6300-7500 \mathrm{mg} \mathrm{L}^{-1}$ for $20 \% \mathrm{PD}$ ), which is in accordance with the $\mathrm{V}$ concentration in the solution for 5\% PD (Fig. 8a). Both results are in good accordance with pH results (Figs. 7c, 8c). In case of abiotic experiments (Fig. 9b), the direct relation with $\mathrm{V}$ extraction has been noted for all examined PD values (Figs. 7b, 8b). The sulfate content was higher for higher PD values, which can be also attributed to higher content of waste in the mixture. The content of elemental sulfur added to each flask was constant [2\% (w/v) for each $50 \mathrm{~mL}$ flask, see Sect. 2.3.2]; therefore, the increasing amount of sulfate in the solution is most likely caused by the bacterial dissolution of sulfur from spent catalyst. However, the higher PD value was not favorable for higher V extraction. Probable reasons were mentioned already, namely improper diffusion or shortage of oxygen caused by high amount of waste or improper mixing [50]. This phenomenon has to be checked in further studies to optimize V extraction for higher PD values, which will allow to reduce costs attached to the preparation of the solution.

The coefficients for chemical leaching show that, for different pulp densities applied, the controlling step might 
Fig. 9 Sulfate content in the bioleaching (a) and abiotic control (b) solution from spent catalyst as a function of time. $P D$ pulp density
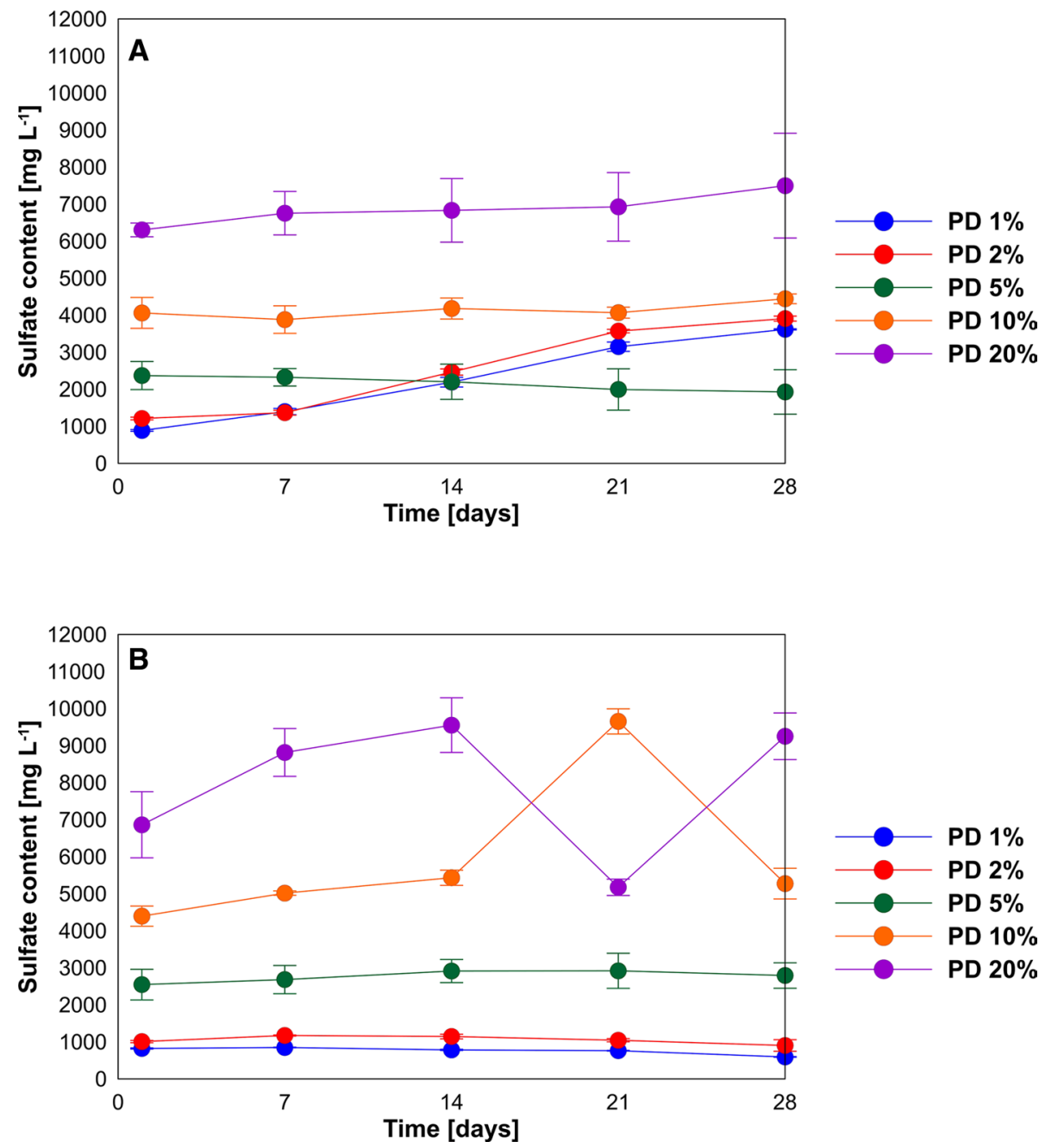

be different. In case of $1 \%$ and $10 \%$ PD, the SCM model fits better for experimental data, and solid product layer control seems to be the rate-determining step, whereas for other PD values, the fluid film diffusion (also SCM) governs the process (Table 2). The effect of pulp density did not reveal changes in kinetic controlling mechanism (solid product layer-SCM), but resulted in better fit to the model. The increase of acid molar concentration from 0.1 to $1 \mathrm{M}$ caused that the SPM model fits perfectly for the data; however, the mechanism of the reaction remained similar (fluid film diffusion). In case of bioleaching using $1 \% \mathrm{PD}$, the highest $R^{2}$ value was obtained for solid product layer control. However, very similar $R^{2}$ was determined for chemical reaction control, which seems to be the governing mechanism in case of $2 \% \mathrm{PD}$. Therefore, one can assume that, regardless of bioleaching conditions, chemical reaction was the rate-determining step. The results for citric acid are partially similar to the kinetic mechanisms of citric acid leaching of Indonesian saprolitic ores [30] and leaching of celestite with nitric acid [32], where solid product layer was also the governing step of the reaction.

\subsection{Perspectives}

The optimal CA-mediated leaching conditions for $\mathrm{V}$ from SDC observed in this experiment seem to be $2 \% \mathrm{PD}$ and $48 \mathrm{~h}$ reaction time. The mentioned parameters allowed to extract as much as $95 \%$ of total $\mathrm{V}$ present in SDC, that is equal to $29,294 \mathrm{mg} \mathrm{kg}^{-1}$ of $\mathrm{V}$ extracted. The observed leaching yield is quite efficient compared to the experiments carried out by other authors for different catalysts. For example, Lozano and Juan [51] achieved 99\% V extraction from spent sulfuric acid catalyst using three-stage countercurrent process. Likewise, Mazurek [25] extracted as much as $90 \%$ of V from spent catalyst using citric acid. In the study of Ma et al. [52], the authors obtained $\mathrm{V}$ leaching rate at $94.35 \%$ level using microwave-assisted leaching. The possible ways to improve recovery rates of $\mathrm{V}$ from spent catalysts are: (a) addition 
of an oxidizing/reducing agent, such as hydrogen peroxide $\left(\mathrm{H}_{2} \mathrm{O}_{2}\right)$, (b) the increase of CA molar concentration, and (c) increase of the temperature during the extraction. For example, the study of Erüst et al. [23] showed that the addition of $0.1 \mathrm{M} \mathrm{H}_{2} \mathrm{O}_{2}$ and the increase of CA molar concentration to $0.2-\mathrm{M}$ lead to $95 \%$ vanadium extraction yield. The similar yield has been achieved when the temperature increased to $80{ }^{\circ} \mathrm{C}$. The addition of $\mathrm{H}_{2} \mathrm{O}_{2}$ has also been proven to have positive impact on $\mathrm{V}$ extraction yield from spent catalyst when other organic acids, such as oxalic acid, have been applied as lixiviants [53].

The optimal conditions of V bioleaching from SDC sample were established at $1 \%$ PD and 21 days operating time, when as much as $93 \%$ of total $\mathrm{V}$ has been extracted, which is equal to $28,677 \mathrm{mg} \mathrm{kg}^{-1}$ of $\mathrm{V}$ extracted. The $\mathrm{V}$ extraction yield in this experiment is very good. The values reported by other authors, although not obtained on sulfuric acid catalysts, were similar or even better. One of the ways to improve the bioleaching efficiency is to apply the Fe-oxidizing Acidithiobacillus ferrooxidans bacteria. The results obtained by Kim et al. [54] showed that the adapted bacterial cultures (bacteria sampled from mining effluent pond and cultivated in $9 \mathrm{~K}$ medium) similar to Acidithiobacillus ferrooxidans were helpful in recovering $\sim 95 \%$ of $\mathrm{V}$ from spent refinery catalysts. The presence of Sulfobacillus thermooxidans bacterial strain in association with Acidithiobacillus thiooxidans may also be considered supportive in V leaching from spent catalysts. As proven by Wang et al. [55], $\mathrm{V}$ recovery achieved was at a level of $90 \%$ in this manner. The other way to improve $\mathrm{V}$ recovery yield can be to perform the second stage to the bioleaching process. The study of Srichandan et al. [56] proved that the two-stage bioleaching experiment using Acidithiobacillus thiooxidans in both steps or Acidithiobacillus ferrooxidans in the second step may lead to $99 \%$ or $100 \%$ of V recovered from the refinery catalyst. The same study described the alkali leaching (the initial solution $\mathrm{pH}$ was set up to 12.0) as the second step of the experiment, which led to $95 \%$ of $\mathrm{V}$ recovery from the catalyst. Finally, the different sample preparation, such as finer fraction, can be the way to achieve high metal recovery yields, as proven by Pradhan et al. [57], who applied 106- $\mu \mathrm{m}$ particle size ( $94.8 \%$ and $92 \%$ of V recovery, respectively) or Wang et al. [55], who applied $80 \mu \mathrm{m}$ particle size $(90 \%$ $\mathrm{V}$ recovery). On the other hand, crushing and pulverizing the materials are energy-consuming operations; therefore, further focus should rather be given to optimization of processing conditions in regards of bioleaching culture and/or reagent concentration.

The citric acid treatment, as well as bioleaching, can lead to generation of the residue significantly depleted in metals when optimal conditions are applied. This was confirmed for citric acid treatment residue, where XRF measurements showed $96.5 \%$ removal of V. Moreover, the (bio)hydrometallurgical treatment mostly reduces the mobile forms of metals commonly present in the catalysts $[58,59]$. The next step of the research would be the thorough characterization of the obtained residues, not only to prove their environmental inertness, but also to make way to utilize them in an economic way, e.g., as a base for a new catalyst. The other obvious step should also be concentrated on recovery of $\mathrm{V}$ from pregnant leach solutions. The simple and efficient methods for this process were recognized, such as addition of $\mathrm{NH}_{4} \mathrm{Cl}$ leading to ammonium vanadate precipitation [8]. The ionic liquids are also prospective in terms of both leaching and later recovery of $\mathrm{V}$ from spent catalyst [60]. Along with optimizing the leaching parameters, the recovery should also be considered to obtain useful metal product, and possibly to recover the leach solution for the next treatments, which will allow to reduce the costs of the process.

\section{Conclusions}

This study assessed the feasibility of biological (Acidithiobacillus thiooxidans) and chemical (0.1-M and 1-M citric acid) leaching of vanadium from spent catalyst (SDC) originating from sulfuric acid plant in a copper smelter. Based on this study, we demonstrated that: (1) examined catalyst consists mainly of cristobalite/tridymite supporting phase with vanadium pentoxide $\left(\mathrm{V}_{2} \mathrm{O}_{5}\right)$ and several inorganic phases including $\mathrm{NH}_{4} \mathrm{VOF}\left(\mathrm{SO}_{4}\right) \cdot 3 \mathrm{H}_{2} \mathrm{O}$ and $\mathrm{KAl}\left(\mathrm{SO}_{4}\right)_{2}$ salts; (2) chemical extraction using $0.1-\mathrm{M}$ citric acid and $2 \%$ pulp density allowed to recover as much as 95\% of total V from the SDC within $48 \mathrm{~h}$; (3) bioleaching with Acidithiobacillus thiooxidans lasted longer as compared to chemical treatment, but yielded satisfactorily high recovery of $93 \%$ of $\mathrm{V}$ from SDC within 21 days at $2 \%$ pulp density; (4) the optimization of leaching processes, such as combination of chemical and biological leaching or application of second-stage bioleaching is recommended to increase the $\mathrm{V}$ extraction yield from SDC.

Acknowledgements The authors would like to gratefully acknowledge Mr. Wiesław Knap for performing ICP-MS analysis. Mr. Adam Gaweł is thanked for his help in XRD and SEM-EDS analyses. Ms. Monika Wójcik-Bania is acknowledged for performing XRF analysis. The authors would like to thank two anonymous reviewers, whose comments helped to improve the clarity and the quality of the manuscript.

Funding This work has been financially supported by AGH University of Science and Technology [project no. 15.11.140.003] to BM and by The National Science Centre (NCN) in Poland in the frame of SONATA program under the Grant agreement UMO-2018/31/D/ ST10/00738 to AP 


\section{Compliance with ethical standards}

Conflict of interest The authors declare no conflict of interest and/or competing interest.

Open Access This article is licensed under a Creative Commons Attribution 4.0 International License, which permits use, sharing, adaptation, distribution and reproduction in any medium or format, as long as you give appropriate credit to the original author(s) and the source, provide a link to the Creative Commons licence, and indicate if changes were made. The images or other third party material in this article are included in the article's Creative Commons licence, unless indicated otherwise in a credit line to the material. If material is not included in the article's Creative Commons licence and your intended use is not permitted by statutory regulation or exceeds the permitted use, you will need to obtain permission directly from the copyright holder. To view a copy of this licence, visit http://creativecommons.org/licenses/by/4.0/.

\section{References}

1. Bhutto AW, Abro R, Gao S, Abbas T, Chen X, Yu G. Oxidative desulfurization of fuel oils using ionic liquids: a review. J Taiwan Inst Chem E. 2016;62:84-97.

2. Alvarez-Amparán MA, Cedeño-Caero L. $\mathrm{MoO}_{\mathrm{x}}-\mathrm{VO}_{\mathrm{x}}$ based catalysts for the oxidative desulfurization of refractory compounds: influence of $\mathrm{MoO}_{\mathrm{x}}-\mathrm{VO}_{\mathrm{x}}$ interaction on the catalytic performance. Catal Today. 2017;282:133-9.

3. Nikiforova A, Kozhura O, Pasenko O. Leaching of vanadium by sulfur dioxide from spent catalysts for sulfuric acid production. Hydrometallurgy. 2016;164:31-7.

4. Guerrero-Pérez MO. Supported, bulk and bulk-supported vanadium oxide catalysts: a short review with an historical perspective. Catal Today. 2017;285:226-33.

5. Argyle MD, Bartholomew $\mathrm{CH}$. Heterogeneous catalyst deactivation and regeneration: a review. Catalysts. 2015;5(1):145-269.

6. Ksibi M, Elaloui E, Houas A, Moussa N. Diagnosis of deactivation sources for vanadium catalysts used in $\mathrm{SO}_{2}$ oxidation reaction and optimization of vanadium extraction from deactivated catalysts. Appl Surf Sci. 2003;220(1-4):105-12.

7. Nikiforova A, Kozhura O, Pasenko O. Application of lime in twostage purification of leaching solution of spent vanadium catalysts for sulfuric acid production. Hydrometallurgy. 2017;172:51-9.

8. Mazurek K. Recovery of vanadium, potassium and iron from a spent vanadium catalyst by oxalic acid solution leaching, precipitation and ion exchange processes. Hydrometallurgy. 2013;134-135:26-31.

9. Dai Z, Wang L, Tang H, Sun Z, Liu W, Sun Y, Su S, Hu S, Wang Y, Xu K, Liu L, Ling P, Xiang J. Speciation analysis and leaching behaviors of selected trace elements in spent SCR catalyst. Chemosphere. 2018;207:440-8.

10. Marafi M, Rana MS. Metal leaching from refinery waste hydroprocessing catalyst. J Environ Sci Heal A. 2018;53:951-9.

11. Vo PNX, Le-Phuc N, Tran TV, Ngo PT, Luong TN. Oxidative regeneration study of spent $\mathrm{V}_{2} \mathrm{O}_{5}$ catalyst from sulfuric acid manufacture. React Kinet Mech Catal. 2018;125:887-900.

12. Langeslay RR, Kaphan DM, Marshall CL, Stair PC, Sattelberger AP, Delferro M. Catalytic applications of vanadium: a mechanistic perspective. Chem Rev. 2019;119(4):2128-91.

13. Gustafsson JP. Vanadium geochemistry in the biogeosphere-speciation, solid-solution interactions, and ecotoxicity. Appl Geochem. 2019;102:1-25.

14. USGS. Vanadium. 2020. https://pubs.usgs.gov/periodicals/mcs20 20/mcs2020-vanadium.pdf. Accessed 19 Feb 2020.
15. Wang M, Tan Q, Chiang JF, Li J. Recovery of rare and precious metals from urban mines-a review. Front Environ Sci Eng. 2017;11:1-13.

16. Del Carpio E, Hernández L, Ciangherotti C, Villalobos Coa V, Jiménez L, Lubes V, Lubes G. Vanadium: History, chemistry, interactions with $\alpha$-amino acids and potential therapeutic applications. Coordin Chem Rev. 2018;372:117-40.

17. Liu C, Liu T, Zhang Y, Dai Z, Yang Y. Preparation of electrolyte for vanadium redox flow battery from sodium-polyvanadate precipitated wastewater. Sep Purif Technol. 2020;240:116582.

18. Graedel TE, Allwood J, Birat J-P, Reck BK, Sibley SF, Sonnemann G, Buchert M, Hagelüken C. Recycling rates of metals-a status report. a report of the working group on global metal flows to the international resource panel, United Nations Environment Programme. 2011. https://www.resourcepanel.org/file/381/downl oad?token=he_rldvr. Accessed 19 Feb 2020.

19. Watt JAJ, Burke IT, Edwards RA, Malcolm HM, Mayes WM, Olszewska JP, Pan G, Graham MC, Heal KV, Rose NL, Turner SD, Spears BM. Vanadium: a re-emerging environmental hazard. Environ Sci Technol. 2018;52:11973-4.

20. Mohanty J, Rath PC, Bhattacharya IN, Paramguru RK. The recovery of vanadium from spent catalyst: a case study. Miner Process Extract Metall Rev. 2011;120(1):56-60.

21. Wahoud A, Alouche A, Abdulbake M. Sulfuric acid baking and leaching of spent sulfuric acid catalyst. Chem Eng. 2011;55(11):31-4. https://doi.org/10.3311/pp.ch.2011-1.06.

22. Mangini LFK, Guimarães Valt RB, de Santana Ponte MJJ, de Araújo PH. Vanadium removal from spent catalyst used in the manufacture of sulfuric acid by electrical potential application. Sep Purif Technol. 2020;246:116854.

23. Erust C, Akcil A, Bedelova Z, Anarbekov K, Baikonurova A, Tuncuk A. Recovery of vanadium from spent catalysts of sulfuric acid plant by using inorganic and organic acids: laboratory and semi-pilot tests. Waste Manag. 2016;49:455-61.

24. Ognyanova A, Ozturk AT, De Michelis I, Ferella F, Taglieri G, Akcil A, Vegliò F. Metal extraction from spent sulfuric acid catalyst through alkaline and acidic leaching. Hydrometallurgy. 2009;100:20-8.

25. Mazurek K, Białowicz K, Trypuć M. Recovery of vanadium, potassium and iron from a spent catalyst using urea solution. Hydrometallurgy. 2010;103:19-24.

26. Mazurek K. Removal of vanadium, potassium and iron from spent vanadium catalyst by leaching with citric acid at atmospheric pressure. Pol J Chem Technol. 2014;16:59-62.

27. Pathak A, Vinoba M, Kothari R. Emerging role of organic acids in leaching of valuable metals from refinery-spent hydroprocessing catalysts, and potential techno-economic challenges: a review. Crit Rev Env Sci Tec. 2020. https://doi.org/10.1080/10643 389.2019.1709399.

28. Johnson DB. Biomining-biotechnologies for extracting and recovering metals from ores and waste materials. Curr Opin Biotechnol. 2014;30:24-31.

29. Asghari I, Mousavi SM, Amiri F, Tavassoli S. Bioleaching of spent refinery catalysts: a review. J Ind Eng Chem. 2013;19:1069-81.

30. Astuti W, Hirajima T, Sasaki K, Okibe N. Kinetics of nickel extraction from an Indonesian saprolitic ore by citric acid leaching under atmospheric pressure. Miner Metall Process. 2015;32:176-85.

31. Astuti W, Hirajima T, Sasaki K, Okibe N. Comparison of atmospheric citric acid leaching kinetics of nickel from different Indonesian saprolitic ores. Hydrometallurgy. 2016;161:138-51.

32. Kocan F, Hicsonmez U. Leaching kinetics of celestite in nitric acid solutions. Int J Miner Metall Mater. 2019;26:11-20.

33. Levenspiel $\mathrm{O}$. Chemical reaction engineering. 2nd ed. New York: Wiley; 1999. 
34. US EPA. Soil and waste pH, Method 9045D, Rev 0. In: SW-846: Test methods for evaluating solid waste. physical/chemical methods. Washington, DC, USA: Office of Solid Waste. 2004. https ://www.epa.gov/sites/production/files/2015-12/documents/9045d .pdf/. Accessed 19 Feb 2020.

35. Sherman J. The theoretical derivation of fluorescent X-ray intensities from mixtures. Spectrochim Acta. 1955;7:283-306.

36. Shiraiwa T, Fujino N. Theoretical calculation of fluorescent X-ray intensities in fluorescent X-ray spectrochemical analysis. Jpn J Appl Phys. 1966;5:886-99.

37. Potysz A, Lens PNL, van de Vossenberg J, Rene ER, Grybos M, Guibaud G, Kierczak J, van Hullebusch ED. Comparison of $\mathrm{Cu}$, $\mathrm{Zn}$ and $\mathrm{Fe}$ bioleaching from $\mathrm{Cu}$-metallurgical slags in the presence of Pseudomonas fluorescens and Acidithiobacillus thiooxidans. Appl Geochem. 2016;68:39-52.

38. ISO 17294-2:2016. Water quality-application of inductively coupled plasma mass spectrometry (ICP-MS) - part 2: determination of selected elements including uranium isotopes. International Organization for Standardization, July 2016.

39. Calderón H, Endara D. Recovery of vanadium from acid and basic leach solutions of spent vanadium pentoxide catalysts. J Geol Res Eng. 2015. https://doi.org/10.17265/2328-2193/2015.04.006.

40. Niu Z, Zou Y, Xin B, Chen S, Liu C, Li Y. Process controls for improving bioleaching performance of both $\mathrm{Li}$ and $\mathrm{Co}$ from spent lithium ion batteries at high pulp density and its thermodynamics and kinetics exploration. Chemosphere. 2014;109:92-8.

41. Garrels RM. Silica: role in the buffering of natural waters. Science. 1965. https://doi.org/10.1126/science.148.3666.69.

42. Lu J, Dreisinger D, West-Sells P. Acid curing and agglomeration for heap leaching. Hydrometallurgy. 2017;167:30-5.

43. Asghari I, Mousavi SM. Effects of key parameters in recycling of metals from petroleum refinery waste catalysts in bioleaching process. Rev Environ Sci Biotechnol. 2014;13:139-61.

44. Potysz A, Kierczak J, van Hullebusch ED. Perspectives regarding the use of metallurgical slags as secondary metal resourcesa review of bioleaching approaches. J Environ Manag. 2018;219:138-52.

45. Povar I, Spinu O, Zinicovscaia I, Pintilie B, Ubaldini S. Revised Pourbaix diagrams for the vanadium-water system. J Electrochem Sci Eng. 2019. https://doi.org/10.5599/jese.620.

46. Larson JW. Thermochemistry of vanadium $(5+)$ in aqueous solutions. J Chem Eng Data. 1995;40:1276-80.

47. Perrin DD. Organic complexing reagents: structure, behavior and application to inorganic analysis. New York: Wiley; 1964.

48. Bredberg K, Karlsson HT, Holst O. Reduction of vanadium(V) with Acidithiobacillus ferrooxidans and Acidithiobacillus thiooxidans. Bioresour Technol. 2004;92:93-6.

49. Pradhan D, Mishra D, Kim DJ, Ahn GJ, Chaudhury GR, Lee SW. Bioleaching kinetics and multivariate analysis of spent petroleum catalyst dissolution using two acidophiles. J Hazard Mater. 2010;175:267-73.

50. Pradhan D, Kim DJ, Chaudhury GR, Lee SW. Bio-dissolution of $\mathrm{Ni}, \mathrm{V}$ and Mo from spent petroleum catalyst using iron oxidizing bacteria. J Environ Sci Health A. 2010;45:476-82.

51. Lozano LJ, Juan D. Leaching of vanadium from spent sulphuric acid catalysts. Miner Eng. 2001;14:543-6.

52. Ma Z, Liu Y, Zhou J, Liu M, Liu Z. Recovery of vanadium and molybdenum from spent petrochemical catalyst by microwaveassisted leaching. Int J Min Met Mater. 2019;26:33-40.

53. Mulak W, Szymczycha A, Leśniewicz A, Żyrnicki W. Preliminary results of metals leaching from a spent hydrodesulphurization (HDS) catalyst. Physicochem Probl Miner Process. 2006;40:69-76.

54. Kim D-J, Pradhan D, Ahn J-G, Lee S-W. Enhancement of metals dissolution from spent refinery catalysts using adapted bacteria culture-effects of $\mathrm{pH}$ and $\mathrm{Fe}(\mathrm{II})$. Hydrometallurgy. 2010;103:136-43.

55. Wang S, Xie Y, Yan W, Wu X, Wang C-T, Zhao F. Leaching of vanadium from waste $\mathrm{V}_{2} \mathrm{O}_{5}-\mathrm{WO}_{3} / \mathrm{TiO}_{2}$ catalyst catalyzed by functional microorganisms. Sci Total Environ. 2018;639:497-503.

56. Srichandan H, Pathak A, Singh S, Blight K, Kim D-J, Lee SW. Sequential leaching of metals from spent refinery catalyst in bioleaching-bioleaching and bioleaching-chemical leaching reactor: comparative study. Hydrometallurgy. 2014;2014(150):130-43.

57. Pradhan D, Patra AK, Kim D-J, Chung H-S, Lee S-W. A novel sequential process of bioleaching and chemical leaching for dissolving $\mathrm{Ni}, \mathrm{V}$, and Mo from spent petroleum refinery catalyst. Hydrometallurgy. 2013;131-132:114-9.

58. Pathak A, Srichandan H, Kim D-J. Fractionation behavior of metals (Al, Ni, V, and Mo) during bioleaching and chemical leaching of spent petroleum refinery catalyst. Water Air Soil Pollut. 2014;225:1893.

59. Pathak A, Healy MG, Morrison L. Changes in the fractionation profile of $\mathrm{Al}, \mathrm{Ni}$, and Mo during bioleaching of spent hydroprocessing catalysts with Acidithiobacillus ferrooxidans. J Environ Sci Health A. 2018;53:1006-14.

60. Singh R, Mahandra H, Gupta B. Cyphos IL 102 assisted liquidliquid extraction studies and recovery of vanadium from spent catalyst. Miner Eng. 2018;128:324-33.

Publisher's Note Springer Nature remains neutral with regard to jurisdictional claims in published maps and institutional affiliations. 